\title{
Comparative analysis of educational needs of patients with rheumatic diseases selected based on the Polish version of the Educational Needs Assessment Tool (Pol-ENAT)
}

\author{
Matylda Sierakowska ${ }^{1}$, Stanisław Sierakowski ${ }^{2}$, Justyna Sierakowska ${ }^{3}$, Elżbieta Krajewska-Kułak ${ }^{1}$
}

${ }^{1}$ Department of Integrated Medical Care, Medical University of Bialystok, Poland

${ }^{2}$ Department of Rheumatology and Internal Diseases, Medical University of Bialystok, Poland

${ }^{3}$ Department of Foreign Languages, Medical University of Bialystok, Poland

\begin{abstract}
Objectives: Chronic rheumatic diseases, which have a progressive course, lead to large deficits in physical, mental and social functioning. In the process of the planned and systematic education of patients/families, it is extremely important to identify patients' health problems as well as their needs and expectations. Study objectives: To assess the learning needs of patients with rheumatoid arthritis (RA) and systemic sclerosis (SSC).

Material and methods: This was a multicenter, cross-sectional study conducted in seven rheumatology centers in Poland. Health problems were defined as disability (HAQ-DI), pain (Pain VAS), fatigue (Fatigue VAS) and severity of disease (0-100). The educational needs were measured using the Pol-ENAT (0-156). Statistical analysis was performed using PQStat v.1.4.2 and Excel.

Results: The study involved 277 patients with rheumatoid arthritis and 140 with systemic sclerosis. The average age of respondents was comparable in RA ( $53.3 \pm 13.0$ years) and SSC ( $54.1 \pm 14.2$ years). Patients suffered from RA on average for $13.7 \pm 10.6$ years and from SSc for $10.9 \pm 10.3$ years. With age and duration of disease, the health problems worsened $(p<0.05)$. The reported needs of education (Pol-ENAT) were generally at the secondary level - RA 66.4 \pm 29.3 - younger people $(p=0.008)$ and those with early RA $(r=-0.151, p=0.011)$; SSc $71.5 \pm 27.7$ - regardless of age and duration of SSc. Educational needs of patients with SSc correlated with the severity of certain health problems and health evaluation (pain $r=0.334, p<0.001$; fatigue $r=0.243, p=0.004$; severity of disease $r=0.242, p=0.004$ and disability $r=0.291, p<0.001$ )

Conclusions: All patients reported the need for education, although it was slightly higher in patients with SSc. There was a decline in interest in education with progressive disability in RA, while in SSC interest in education increased with the progress and severity of the disease.
\end{abstract}

Key words: rheumatoid arthritis, systemic sclerosis, health problems, educational needs.

\section{Introduction}

Education of patients is an essential part of treatment of any disease of the musculoskeletal system; however, it is particularly important in the case of chronic diseases which bring long-lasting pain and significant dysfunction, as well as lowering of quality of the patients' life [1].
Rheumatological patients need support and advice on how to live with the disease, how to handle problems arising from the limitations due to the physical nature of the difficulties, problems in fulfilling family and professional roles, with stress and suffering. Patients needs help in adapting to new living conditions and in learning about different methods of self-care. It is also necessary

Address for correspondence:

Matylda Sierakowska, Department of Integrated Medical Care, Medical University of Bialystok, Marii Skłodowskiej-Curie 7A, 15-096 Bialystok, Poland, e-mail: matyldasierakowska@gmail.com

Submitted: 5.08.2016; Accepted: 30.08.2016 
to have knowledge concerning the adverse effects of therapy, monitoring early signs of the disease, indicating the involvement of internal organs in the course of the disease, as well as life-threatening conditions [2].

Rheumatoid arthritis (RA) is the most commonly occurring systemic connective tissue disease with an immunological background. It is characterized by non-specific, symmetric arthritis that leads to impaired movement, progressive destruction, presence of extra-articular changes, including complications in many organs. It is also characterized by its chronic course, with periods of exacerbation and remission. It can lead to large deficits in the area of the physical as well as mental and social functioning [3].

The disease prevalence is about $1 \%$ in Caucasians. It is estimated that about 400,000 people are suffering from inflammatory arthritis diseases including RA in Poland. Most patients become ill during their $4^{\text {th }}-5^{\text {th }}$ decade of life, with the vast majority being women [4].

One of the main elements in the therapeutic approach to RA is education, whose aim is to help the patient maintain as much functional capacity and social activity as possible [1].

Another connective tissue disease is systemic sclerosis (SSc), scleroderma, which differs from RA in terms of etiology, pathogenesis and its clinical course. It is characterized by abnormal morphology and functioning of blood vessels and progressive fibrosis of skin and internal organs, which leads to their failure [5].

Systemic sclerosis is not a single disease. The most common clinical form of SSc is limited systemic sclerosis (ISSc) (approx. 2/3 of cases). A more severe form of $\mathrm{SSc}$ is diffuse systemic sclerosis (dSSc) (approx. 1/3 of all cases of SSc) [5]. Systemic sclerosis prevalence is estimated to be between 3 and 24 per 100,000 population and appears to be higher in North America and Australia as compared to Europe and Japan [6]. It is estimated that in Poland SSc affects around 10,000 people, mostly women. The peak incidence is between 35 and 55 years of age [7].

Standard therapy for SSc is an organ-specific treatment, based on the principles of complexity and individualization. The patients' education occupies an important place here; it is primarily aimed at preparing the patient for self-care and self-monitoring of their health state, paying particular attention to monitoring of symptoms of organ damage (scleroderma renal crisis [SRC], pulmonary arterial hypertension [PAH]) [7].

It can be assumed that properly conducted education, in relation to both patients with RA and those with SSc, would mitigate the course of these chronic diseases, slow down their progression and reduce complications.
Rheumatologic patients' education is widely practiced in most European countries. The authors of this paper conducted a detailed study on the educational needs of patients with RA [8] and SSc [9], based on the Polish version of the ENAT, analyzing them in the context of socio-demographic data, which are health problems common to both diseases. This study is an attempt to present the existing differences, as well as proving how different the needs might be depending on the type of connective tissue disease. The authors have tried to demonstrate the importance of so-called "tailor-made" education in rheumatic diseases.

Specific objectives: to identify the differences in the effects of selected health problems of patients with RA and SSC on the daily functioning; to analyze the relationship of the socio-demographic variables and duration of the disease with the intensity of selected health problems and educational needs, depending on the type of rheumatic disease and the present health problems.

\section{Material and methods}

The study was conducted at the Department of Rheumatology and Internal Diseases, Medical University of Bialystok, and in 6 other rheumatologic centers in Poland, on 277 patients with RA and 140 with SSc. The inclusion criterion for the study was to identify rheumatoid arthritis, based on the ACR/EULAR 2010 criteria, and systemic sclerosis based on the ACR/EULAR 2013 criteria and the age $\geq 18$ years. The study has been approved by the Bioethics Committee at the Medical University of Bialystok (R-I-002/249/2014, R-I-002/87/2015). The patients expressed their written consent to participate in the study.

The method used in the study was a diagnostic survey: the Polish version of the Educational Needs Assessment Tool (Pol-ENAT) (0-156), the Health Assessment Questionnaire (HAQ DI) (0-3), Pain Visual Analogue Scale (VAS), Fatigue VAS, and overall severity of disease from the patients' perspective (VAS 0-100).

The Polish Needs Assessment Tool (Pol-ENAT) is a tool used for systematic assessment of the educational needs of patients with rheumatic diseases. The questionnaire was translated, validated and underwent a cultural adaptation to Batton in Poland at the Medical University of Bialystok in 2012, separately for patients with RA and for patients with SSC [10]. The tool is a questionnaire completed by the patient; it contains 39 items, grouped into seven domains: managing pain (0-24), movement (0-20), feelings (0-16), the process of disease (0-28) treatments (0-28), self-help measures (0-24) and support systems (0-16). Adding up all the transformed domain scores, ENAT gives the total score, which is an estimate of the patient's educational needs (range $=0-156)$ [11-13]. 


\section{Data analysis}

For the statistical analysis of the collected data, the method of the description and the study of the interaction between the quantitative and qualitative traits were used. For independent groups, one-way ANOVA to verify the hypothesis of equality of means for studied variables was used. For nonparametric data, the statistical test of independence based on chi-square was analyzed. It was also examined whether there is a linear relationship between the measured traits (Pearson correlation coefficient $r$ ). The level of significance $\alpha=0.05$. Statistical analysis was performed using PQStat v.1.4.2 and Excel.

\section{Results}

The study included 277 patients with RA $(n=277)$, including 214 women (77.3\%) and 140 patients with SSc (limited systemic sclerosis - ISSC $n=83,59.3 \%$ of embodiment diffuse systemic sclerosis - dSSc $n=57$, 40.7\%), 125 women (89.3\%). The mean age of the patients with RA was $53.3 \pm 13.0$, and that of SSc was comparable $-54.1 \pm 14$.2. The majority of respondents in both groups were in the age $>41$ years. Duration of RA was on average $13.7 \pm 10.6$ and SSc $10.9 \pm 10.3$ (Table I).

The analysis of analogue scales in patients with RA revealed that selected health problems were assessed at the secondary level. The mean Pain VAS (0-100) score was $54.9 \pm 23.2$, fatigue $52.9 \pm 22.0$, and the overall impact of the disease on daily functioning was $54.2 \pm 21.3$. Patients with RA also assessed their performance in activities of daily living (HAQ DI 0-3). They obtained average value of $1.4 \pm 0.7$ (Table I).

The greatest intensity of the studied SSc patients' health was related mainly to fatigue: Fatigue VAS 46.6 \pm 29 .5. The average value of the pain (Pain VAS) was lower than in RA and was $39.2 \pm 29$ and the sense of disease activity was noted at $44.4 \pm 26.4$. Disability in patients

Table I. Characteristics of patients and outcomes

\begin{tabular}{|c|c|c|}
\hline \multirow[t]{3}{*}{ Variable (score range) } & \multicolumn{2}{|c|}{ Rheumatic disease } \\
\hline & $\begin{array}{l}\text { Rheumatoid arthritis (RA) } \\
\qquad n=277\end{array}$ & $\begin{array}{l}\text { Systemic sclerosis (SSc) } \\
\qquad n=140\end{array}$ \\
\hline & \multicolumn{2}{|c|}{ Mean $( \pm S D)$} \\
\hline Age & $53.3(13.0)$ & $54.1(14.2)$ \\
\hline$\leq 40-$ number $(\%)$ & $46(16.6)$ & $25(18.9)$ \\
\hline 41-60 - number (\%) & $155(55.0)$ & $64(45.7)$ \\
\hline$>60$ - number (\%) & $76(27.4)$ & $51(36.4)$ \\
\hline Disease duration & $13.7(10.6)$ & $10.9(10.3)$ \\
\hline $0-5-$ number $(\%)$ & $59(21.3)$ & $54(38.6)$ \\
\hline 6-10- number (\%) & $80(28.9)$ & $38(27.1)$ \\
\hline 11-20 - number (\%) & $86(31.1)$ & $29(20.7)$ \\
\hline$\geq 21-$ number $(\%)$ & $52(18.8)$ & $19(13.6)$ \\
\hline Gender - number of women (\%) & $214(77.3)$ & $125(89.3)$ \\
\hline \multicolumn{3}{|l|}{ Educational needs (Pol-ENAT) } \\
\hline Managing pain (0-24) & $11.8(5.0)$ & $12.4(5.6)$ \\
\hline Movement (0-20) & $7.9(4.1)$ & $8.9(5.1)$ \\
\hline Feelings (0-16) & $7.6(4.3)$ & $8.1(4.4)$ \\
\hline Disease process (0-28) & $10.6(6.5)$ & $15.0(5.8)$ \\
\hline Treatments (0-28) & $11.0(6.5)$ & $7.7(5.6)$ \\
\hline Self-help (0-24) & $11.0(5.2)$ & $12.5(6.5)$ \\
\hline Support (0-16) & $5.5(3.9)$ & $7.0(3.5)$ \\
\hline Total ENAT (0-156) & $66.4(29.3)$ & $71.5(27.7)$ \\
\hline HAQ DI (0-3) & $1.4(0.7)$ & $1.1(0.7)$ \\
\hline Pain VAS (0-100) & $54.9(23.2)$ & $39.2(29.0)$ \\
\hline Fatigue VAS (0-100) & $52.9(22.0)$ & $46.6(29.5)$ \\
\hline Disease severity (0-100) & $54.2(21.3)$ & $44.4(26.4)$ \\
\hline
\end{tabular}


Table II. Correlation between health problems and age, disease duration and educational needs of RA and SSc patients

\begin{tabular}{|c|c|c|c|c|}
\hline \multirow[t]{2}{*}{ Variable (score range) } & \multirow{2}{*}{$\begin{array}{l}\text { Rheumatic } \\
\text { disease }\end{array}$} & Age & Disease duration & Total Pol-ENAT \\
\hline & & ${ }^{{ }^{1} r_{p}}{ }_{p \text {-value }}$ & ${ }_{p \text {-value }}^{{ }^{1} r_{p}}$ & ${ }_{p \text {-value }}^{{ }^{1} r_{p}}$ \\
\hline \multirow[t]{2}{*}{ Pain VAS (0-100) } & RA & $0.186(0.002)$ & $0.091(0.13)$ & $-0.000(0.99)$ \\
\hline & SSC & $0.294(<0.001)$ & $0.342(<0.001)$ & $0.334(<0.001)$ \\
\hline \multirow[t]{2}{*}{ Fatigue VAS (0-100) } & RA & $0.147(0.014)$ & $0.128(0.033)$ & $0.025(0.68)$ \\
\hline & $\mathrm{SSC}$ & $0.273(0.001)$ & $0.197(0.020)$ & $0.243(0.004)$ \\
\hline \multirow[t]{2}{*}{ Severity of disease $(0-100)$} & RA & $0.248(<0.001)$ & $0.181(0.002)$ & $-0.007(0.90)$ \\
\hline & SSC & $0.250(0.003)$ & $0.259(0.002)$ & $0.242(0.004)$ \\
\hline \multirow[t]{2}{*}{ HAQ DI (0-3) } & RA & $0.474(<0.001)$ & $0.442(<0.001)$ & $-0.097(0.11)$ \\
\hline & SSC & $0.254(0.002)$ & $0.344(<0.001)$ & $0.291(<0.001)$ \\
\hline
\end{tabular}

'Pearson's correlation coefficient $r$

with SSc was also higher than in patients with RA, but revealed certain difficulties - HAQ DI $1.1 \pm 0.7$ (Table I).

The detailed analysis of data, using the Pearson correlation coefficient ( $r$ ), indicates that the age of patients with RA had a significant impact on the severity of al investigated symptoms. There was a positive linear relationship in the assessment of the variables studied (Pain VAS $r=0.186, p=0.002$; Fatigue VAS $r=0.147$ $p=0.014$; the overall impact of the disease on daily functioning $r=0.248, p<0.001$ ) (Table II).

Older age of patients with SSc also significantly influenced the severity of the reported symptoms (Pain VAS $r=0.294, p<0.001$; Fatigue VAS $r=0.273, p=0.001$; the impact of the disease on daily activities $r=0.250$, $p=0.003$.

The results obtained on the basis of HAQ DI demonstrated that with age, the patients from both test groups had poorer performance in self-care (RA $r=0.474$, $p<0.001$; SSC $r=0.254, p=0.002)$. The study has revealed that along with the duration of RA $(r=0.442)$ and SSc $(r=0.334)$ the patients reported lower efficiency in everyday activities (HAQ DI) $(p<0.001)$ (Table II).

In the group with RA there was not observed a significant relationship between the duration of the disease and the degree of symptoms tested (with the exception of the impact on daily activity: $r=0.181, p=0.002$ ), whereas in patients with SSc there was observed a correlation with the sensation of pain in the joints (Pain VAS) $(r=0.342, p<0.001)$, the occurrence of fatigue (Fatigue VAS) $(r=0.147, p=0.020)$ and a subjective assessment of the activity of SSc $(r=0.259, p=0.002)$ (Table II).

\section{Analysis of the Pol-ENAT questionnaire}

The overall assessment of educational needs of respondents (0-156) with RA and SSc revealed needs and expectations concerning increasing knowledge about the disease at a medium level: RA $66.4 \pm 29.3$, SSc $71.5 \pm 27.7$.

In the case of rheumatoid arthritis in general, quite a lot of interest was noted in the domains of coping with pain $(11.8 \pm 5)$, self-care $(11 \pm 5.2)$ and feelings $(7.6 \pm 4.3)$.

The respondents with scleroderma declared mainly interest in the domains of the disease process $(15 \pm 5.8)$, self-care methods $(12.5 \pm 6.5)$ and pharmacological and non-pharmacological methods of dealing with pain (12.4 $\pm 5.6)$ (Table I).

The detailed analysis of the results of the Pol-ENAT questionnaire revealed significantly higher needs of respondents with RA aged $\leq 40$ years, in emotion and course of the disease $(p<0.001)$ and dealing with the pain $(p=0.001)$, self-care $(p=0.002)$ and treatment $(p=0.029)$.

Also in the group of patients with early RA there was observed a significantly higher need for education in the domain of coping with emotions than in patients in the later period of the disease $(r=-0.198, p<0.001)$. In contrast, respondents with an RA duration of $0-5$ years reported higher educational needs concerning coping with pain $(r=-0.226, p<0.001)$, the disease process $(r=-0.213$, $p<0.001)$, and self-care $(r=-0.199, p<0.001)$, as well as the treatment $(r=-0.150, p=0.012)$ (Table III).

The analysis of SSc patients' data revealed that independent variables such as age and duration of illness did not affect the educational needs of patients.

Educational needs were different, and depended on the perceived ailments. In patients with RA there was no significant correlation with the examined variables, whereas the group with SSc showed a positive linear correlation between the overall average value of Pol-ENAT $(71.5 \pm 27.7)$ and subjective assessment of the severity of pain (Pain VAS) $(r=0.334, p<0.001)$, fatigue (Fatigue 
Table III. Effect of age and disease duration on the needs for education using Pol-ENAT questionnaire of RA and SSc patients

\begin{tabular}{|c|c|c|c|c|c|c|c|c|c|c|}
\hline & \multicolumn{5}{|c|}{ Age Mean $( \pm S D)$} & \multicolumn{5}{|c|}{ Disease duration Mean $( \pm S D)$} \\
\hline Pol-ENAT & & $\leq 40$ & $41-60$ & $>60$ & ${ }^{2} p$ value & $0-5$ & $6-10$ & $11-20$ & $>20$ & ${ }^{{ }^{1} r_{p}}{ }_{p}$-value \\
\hline \multirow[t]{2}{*}{ TOTAL } & RA & $75.0(27.6)$ & $67.7(28.4)$ & $58.7(30.6)$ & 0.008 & $77.1(31.4)$ & $67.8(27.2)$ & $59.4(23.6)$ & $63.8(35.2)$ & $\begin{array}{l}-0.151 \\
(0.011)\end{array}$ \\
\hline & SSC & $66.9(22.4)$ & $71.1(30.4)$ & $74.4(26.8)$ & 0.54 & $70.2(25.0)$ & $67.9(31.2)$ & $76.0(25.9)$ & $76.6(30.9)$ & $\begin{array}{l}0.113 \\
(0.18)\end{array}$ \\
\hline \multicolumn{11}{|l|}{ DOMAINS } \\
\hline \multirow{2}{*}{$\begin{array}{l}\text { Managing } \\
\text { pain } \\
(0-24)\end{array}$} & RA & $13.5(5.2)$ & $12.1(4.6)$ & $10.2(5.2)$ & 0.001 & $13.6(5.7)$ & $12.2(4.4)$ & $10.8(4.3)$ & $11.0(5.4)$ & $\begin{array}{c}-0.226 \\
(<0.001) \\
\end{array}$ \\
\hline & SSC & $10.5(4.5)$ & $12.5(5.8)$ & $13.2(5.8)$ & 0.14 & $12.3(5.9)$ & $11.9(5.6)$ & $13.0(5.4)$ & $12.7(5.4)$ & $\begin{array}{l}0.035 \\
(0.68)\end{array}$ \\
\hline \multirow[t]{2}{*}{$\begin{array}{l}\text { Movement } \\
(0-20)\end{array}$} & RA & $8.1(4.0)$ & $8.1(4.0)$ & $7.4(4.4)$ & 0.44 & $8.4(4.5)$ & $7.9(3.9)$ & $7.5(3.1)$ & $8.1(5.4)$ & $\begin{array}{c}-0.038 \\
(0.53)\end{array}$ \\
\hline & SSC & $7.5(5.2)$ & $9.3(5.2)$ & $9.0(5.0)$ & 0.29 & $8.4(5.0)$ & $8.4(6.0)$ & $10.0(4.5)$ & $9.5(4.7)$ & $\begin{array}{l}0.124 \\
(0.14)\end{array}$ \\
\hline \multirow[t]{2}{*}{$\begin{array}{c}\text { Feelings } \\
(0-16)\end{array}$} & RA & $9.7(4.3)$ & $7.6(4.2)$ & $6.3(4.2)$ & $<0.001$ & $9.8(4.5)$ & $7.2(4.0)$ & $6.8(4.0)$ & $7.1(4.6)$ & $\begin{array}{c}-0.198 \\
(<0.001)\end{array}$ \\
\hline & SSC & $6.9(4.2)$ & $8.8(4.4)$ & $7.7(4.5)$ & 0.14 & $8.0(4.3)$ & $7.8(4.7)$ & $8.9(4.3)$ & $7.6(4.5)$ & $\begin{array}{l}0.009 \\
(0.92) \\
\end{array}$ \\
\hline \multirow{2}{*}{$\begin{array}{c}\text { Arthritis } \\
\text { process } \\
(0-28)\end{array}$} & RA & $13.8(7.0)$ & $11.0(6.2)$ & $8.0(5.9)$ & $<0.001$ & $12.5(7.2)$ & 11.7 (6.6) & $9.1(4.8)$ & $9.5(7.4)$ & $\begin{array}{c}-0.213 \\
(<0.001)\end{array}$ \\
\hline & SSC & $15.0(4.8)$ & $14.6(6.4)$ & 15.5 (5.4) & 0.72 & $14.9(5.6)$ & 13.7 (5.9) & $15.6(4.7)$ & $17.1(7.1)$ & $\begin{array}{l}0.154 \\
(0.07)\end{array}$ \\
\hline \multirow[t]{2}{*}{$\begin{array}{l}\text { Treatments } \\
\quad(0-28)\end{array}$} & RA & $12.2(5.6)$ & $11.4(6.4)$ & $9.4(7.0)$ & 0.029 & $12.7(7.1)$ & 11.4 (5.7) & $9.6(5.6)$ & $10.9(7.8)$ & $\begin{array}{l}-0.150 \\
(0.012)\end{array}$ \\
\hline & SSC & $6.4(4.0)$ & $7.6(5.8)$ & $8.6(6.0)$ & 0.27 & $7.3(4.4)$ & $6.9(5.7)$ & $8.8(5.9)$ & $9.1(7.7)$ & $\begin{array}{l}0.132 \\
(0.12) \\
\end{array}$ \\
\hline \multirow{2}{*}{$\begin{array}{l}\text { Self-help } \\
\text { measures } \\
(0-24)\end{array}$} & RA & $11.7(4.2)$ & $11.6(5.3)$ & $9.3(5.0)$ & 0.002 & $12.5(5.4)$ & $11.8(5.2)$ & $9.9(4.3)$ & $10.0(5.6)$ & $\begin{array}{c}-0.199 \\
(<0.001)\end{array}$ \\
\hline & SSC & $13.2(5.9)$ & $11.9(6.4)$ & $13.0(6.8)$ & 0.57 & $12.4(6.1)$ & $12.1(7.2)$ & $12.7(6.3)$ & $13.2(6.5)$ & $\begin{array}{l}0.068 \\
(0.43) \\
\end{array}$ \\
\hline \multirow{2}{*}{$\begin{array}{c}\text { Support } \\
\text { systems } \\
(0-16)\end{array}$} & RA & $6.0(3.9)$ & $5.7(3.9)$ & $4.6(3.8)$ & 0.06 & $5.9(4.5)$ & $5.6(3.6)$ & $4.9(3.1)$ & $5.5(4.7)$ & $\begin{array}{c}-0.072 \\
(0.23)\end{array}$ \\
\hline & SSC & $7.4(3.6)$ & $6.4(3.4)$ & $7.4(3.7)$ & 0.26 & $6.8(3.2)$ & $6.7(4.0)$ & $7.1(3.7)$ & $7.6(9.2)$ & $\begin{array}{l}0.055 \\
(0.52)\end{array}$ \\
\hline
\end{tabular}

${ }^{1}$ Pearson's correlation coefficient $r$; ${ }^{2}$ the univariate ANOVA for independent groups

VAS) $(r=0.243, p=0.004)$, general sense the impact of disease activity $(r=0.242, p=0.004)$ and the degree of physical disability (HAQ DI) $(r=0.291, p<0.001)$ (Table II).

\section{Discussion}

Patients suffering from chronic rheumatic disease face three kinds of problems, i.e. loss or severe restriction of the fundamental functionality and continuous suffering from pain and other symptoms resulting from the disease; the secondary consequences of the disease that limit the ability of an individual to perform further social functioning; and the negative impact of the disease on self-esteem and life expectations. All of these factors result in creating a spiral of passivity and apathy, a sense of hopelessness and uselessness, which in turn reduces the quality of patients' life.

The American College of Rheumatology and the European League of Associations for Rheumatology (ACR/ EULAR 2010) recommend goals for the treatment of rheumatoid arthritis that aim at long-term maintenance of the best possible patients' life quality. This can be achieved by monitoring symptoms, lowering the level of pain, and preventing destructive changes in the joints. 
The aim is to normalize the physical fitness and the ability to participate in social life [14].

In systemic sclerosis a priority objective is also preventing the complications from internal organs, as well as alleviation of pain, protection of the joints, pain management, prevention of infections, emotional support and health education [7].

In the process of planned, systematic education of the patient/family it is extremely important to identify the needs and expectations of the patient, as well as to identify his/her health problems and difficulties in the somatic, social and psychological spheres.

The aim of the study was to perform a comparative analysis of educational needs of patients diagnosed with rheumatoid arthritis or systemic sclerosis, in the context of health problems common to both diseases, expressed in a subjective assessment.

The analysis of health parameters of patients with RA and SSc, based on linear scales, showed the assessment of studied variables at a medium level, although the patients with SSc expressed slightly lower severity of symptoms.

The progressive nature of rheumatoid arthritis causes worse and worse functioning of the patients [15]. In our study it was observed that the duration of the disease impacts the progressive lack of functionality. The patients reported increasing difficulty in activities of daily living along with the duration of both RA and SSc $(p<0.001)$.

The role of nurses in the therapeutic treatment of rheumatic diseases in the patients' education is to design and to teach strategies of coping with the disease and to increase the capacity of self-care [2]. A Dutch study showed that patients' expectations of the rheumatic nurses were focused mainly on education, promoting self-care, well-organized care and emotional support [16].

Our analysis, based on the Polish version of the Pol-ENAT, showed that the vast majority of patients with RA and SSC (> 80\%) would like to receive information that might help them in coping with the disease. Overall assessment of educational needs showed interests in education of RA subjects at a secondary level (66.4), and in SSc subjects at a slightly higher level (71.5).

The Austrian research confirmed the high interest in education among RA patients [17]. These results are consistent with previous studies that indicated a high demand for information on diseases and therapies [18, 19].

Mendelson and Poole [20] believe that SSc patients' positive attitude to fighting the disease can be achieved through accurate information, support and therapeutic activities.

The evaluation of specific domains of Pol-ENAT showed the greatest demand of Polish patients with RA on knowledge of the methods of coping with pain, self-care and feelings. Also the researchers who used the Dutch version of the Educational Needs Assessment (DENAT) pointed to the need for knowledge of their patients in the field of the arthritis process, treatments for health professionals and self-help measures [21].

Respondents suffering from SSc were particularly interested in the domain of the process of disease, selfcare methods, coping with pain and emotions.

Van Eijk-Hustings et al. [22] also demonstrated that patients with rheumatic diseases, mainly RA, are interested in education about the disease itself, treatments, and side effects of pharmacological therapy applied.

The main psychological problem of patients suffering from RA is anxiety that is associated with the recurrent inflammatory disease and pain [23, 24]. Symptoms of anxiety and depression are relatively common in patients with RA [25]. This is also confirmed by research based on the Austrian-German version of the ENAT (OENAT); the study also pointed to the large interest, especially among women, in topics related to coping with emotions [17].

In our study the educational needs concerning dealing with emotions were rated as quite important, both among patients with RA and those with SSc. Women suffering from RA wanted to know significantly more about dealing with emotions than men, especially in early RA (0-5 years) ( $p<0.001)$. Younger patients also indicated interest in issues related to the arthritis process $(p<0.001)$, coping with pain $(p=0.001)$, self-care $(p=0.002)$ and treatments $(p=0.029)$.

The study based on the DENAT questionnaire also indicated that younger patients with RA have a higher deficit of knowledge in the domains concerning coping with pain, emotions and getting support than older ones [21].

Neame et al. and Adab et al. [18, 19] confirmed less interest in education together with the duration of RA, which goes hand in hand with progressive functional disability.

Respondents suffering from SSc declared relatively high interest in education, regardless of age and duration of illness. Other studies also showed that patients with scleroderma report the need for clear and effective information at every stage of the disease [26].

Mendelson and Poole [20] emphasized that the patients with systemic sclerosis need knowledge on how to deal with the limitations of a physical nature, dysfunction of manual and mental support, and to adapt to physical changes in the body and restrictions in the future.

To conclude, it should be noted that the aim of patients' education is to adapt them to living with a chronic, progressive disease of the connective tissue, helping them in adaptation and organization of working and social life, which is a difficult issue for a great number of patients. A patient with rheumatic disease should also be prepared 
for conscious participation in the process of treatment, nurturing and self-care. Therefore, it is very important to obtain professional help, support and education that is planned, systematic, but also focused on the needs and capabilities of the individual patient's health [27-29].

The study has shown that in the planning of health education, diagnosis is very important, because it determines the patients' knowledge deficit, their expectations and difficulties in self-care. Each patient should be approached individually, without previous assumptions of what the patient already knows about the disease. The specific nature of the disease should be taken into account because, as it has been demonstrated by the study, the needs of RA and SSc patients are different.

\section{Conclusions}

The severity of the health problems of patients with RA and SSc (pain, fatigue, disability) are significantly affected by their age and the duration of disease. The majority of patients, regardless of the type of rheumatic disease, declare the need for education, although it is slightly higher in patients with SSC.

The patients with RA are interested in education while they are younger and with early RA, but these variables have no effect on the subjects with SSc.

An important common interest for all the respondents is the methods of dealing with pain and self-care. In addition, patients with RA emphasize the importance of knowledge concerning coping with lower emotional moods (mainly female), and SSc patients are interested in information about the diagnosis, the disease, its course and prognosis.

In patients with RA there was observed a decline in interest in education along with progressive disability, while in SSc patients the interest increases with the progress and severity of the disease.

\section{Acknowledgements}

This study was supported by a research project from the Medical University of Bialystok, Poland (UMB: 14310882 P; N/ST/ZB/15/002/3310 (153-10655P).

The authors declare no conflict of interest.

\section{References}

1. Sierakowska M, Lewko J, Krajewska K, et al. Jak żyć z przewlekłą chorobą reumatyczną - rola pielęgniarki w edukacji pacjentów. Problemy Pielęgniarstwa 2008; 16: 199-204.

2. Van Eijk-Hustings Y, van Tubergen A, Bostrom C, et al. EULAR recommendations for the role of the nurse in the management of chronic inflammatory arthritis. Ann Rheum Dis 2012; 71: 13-19.
3. Aletaha D, Neogi T, Silman AJ, et al. 2010 Rheumatoid Arthritis Classification Criteria An American College of Rheumatology/ European League Against Rheumatism Collaborative Initiative. Arthritis Rheum 2010; 62: 2569-2581.

4. Wiland P, Maciążek-Chyra B. Stan reumatologii w Polsce w 2012 roku. Reumatologia 2012; 50: 263-275.

5. van den Hoogen F, Khanna D, Fransen J, et al. 2013 classification criteria for systemic sclerosis: an American college of rheumatology/European league against rheumatism collaborative initiative. Ann Rheum Dis 2013; 72: 1747-1755.

6. Ranque B, Mouthon L. Geoepidemiology of systemicsclerosis. Autoimmun Rev 2010; 9: A311-318.

7. Sierakowski S, Sierakowska M. Twardzina układowa. In: Postępy reumatologii klinicznej. Zimmermann-Górska I (ed.). Wyd. Lekarskie PZWL, Warszawa 2014; 189-212.

8. Sierakowska M, Klepacka M, Sierakowski S, et al. Assessment of education requirements for patients with rheumatoid arthritis, based on the Polish version of the Educational Needs Assessment Tool (Pol-ENAT), in the light of some health problems. A cross-sectional study. Ann Agric Environ Med 2016; 23: 361-367.

9. Sierakowska M, Sierakowski S, Sierakowska J, et al. Adaptation and validation of the Systemic Sclerosis Quality of Life Questionnaire into polish: item analysis using rash models. Ann Rheum Dis 2016; 75 (suppl 2): 1301.

10. Sierakowska M, Sierakowski S, Sierakowska S, et al. Developing the Polish Educational Needs Assessment Tool (Pol-ENAT) in rheumatoid arthritis and systemic sclerosis: a cross-cultural validation study using Rasch analysis. Qual Life Res 2014; 24: 721-733.

11. Hill J, Tennant A, Adebajo A. Further development of an educational needs assessment tool (ENAT) for patients with rheumatoid arthritis. Arthritis Rheum 2004; 50: 274-275.

12. Ndosi M, Tennant A, Bergsten $U$, et al. Cross-cultural validation of the Educational Needs Assessment Tool in RA in 7 European countries. BMC Musculoskelet Disord 2011; 12: 110.

13. Ndosi M, Bremander A, Hamnes B, et al. Validation of the educational needs assessment tool as a generic instrument for rheumatic diseases in seven European countries. Ann Rheum Dis 2014; 73: 2122-2129.

14. Smolen JS, Landewé R, Breedveld FC, et al. EULAR recommendations for the management of rheumatoid arthritis with synthetic and biological disease-modifying antirheumatic drugs: 2013 update. Ann Rheum Dis 2014; 73: 492-509.

15. Filipowicz-Sosnowka A, Rupiński R. Ocena jakości życia chorych na reumatoidalne zapalenie stawów za pomocą badań ankietowych. Reumatologia 2005; 43: 138-145.

16. Neville C, Fortin PR, Fitzcharles MA, et al. The needs of patients with arthritis: the patient's perspective. Arthritis Care Res 1999; 12: 85-95.

17. Drăgoi RG, Ndosi $M$, Sadlonova $M$, et al. Patient education, disease activity and physical function: can we be more targeted? A cross sectional study among people with rheumatoid arthritis, psoriatic arthritis and hand osteoarthritis. Arthritis Res Ther 2013; 15: R156.

18. Neame R, Hammond A, Dieghton C. Need for information and for involvement in decision making among patients with rheumatoid arthritis: a questionnaire survey. Arthritis Rheum 2005; 53: 249-255. 
19. Adab P, Rankin EC, Witney AG, et al. Use of a corporate needs assessment to define the information requirements of an arthritis resource centre in Birmingham: comparison of patients' and professionals' views. Rheumatology 2004; 43: 1513-1518.

20. Mendelson C, Poole JL. Become your own advocate: advice from women living with scleroderma. Disabil Rehabil 2007; 29: 1492-1501.

21. Meesters J, Vliet Vlieland T, Hill J, et al. Measuring educational needs among patients with rheumatoid arthritis using the Dutch version of the Educational Needs Assessment Tool (DENAT). Clin Rheumatol 2009; 28: 1073-1077.

22. Van Eijk-Hustings Y, Ammerlaan J, Voorneveld-Nieuwenhuis H, et al. Patient'needs and expectations with regard to rheumatology nursing care: results of multicenter focus group interviews. Ann Rheum Dis 2013; 72: 831-835.

23. Newth S, Delongis A. Individual differences, mood and coping with chronic pain in rheumatoid arthritis: a daily process analysis. Psychol Health 2004; 19: 283-305.

24. Wysocka-Skurska I, Sierakowska M, Sierakowski S. Ocena jakości życia pacjentów z reumatoidalnym zapaleniem stawów w zależności od stosowanej terapii farmakologicznej. Reumatologia 2012; 50: 16-23.

25. Isik A, Koca SS, Ozturk A, et al. Anxiety and depression in patients with rheumatoid arthritis. Clin Rheumatol 2007; 26: 872-878.

26. Godard D. The needs of patients with systemic sclerosis what are the difficulties encountered? Autoimmun Rev 2011; 10: 291-294.

27. Mäkeläinen P, Vehviläinen-Julkunen K, Pietilä AM. Rheumatoid arthritis patients' education - contents and methods. J Clin Nurs 2007; 16: 258-267.

28. Arvidsson S, Bergman S, Arvidsson B, et al. Effects of a selfcare promoting problem-based learning programme in people with rheumatic diseases: a randomized controlled study. J Adv Nurs 2013; 69: 1500-1514.

29. Samuelson UK, Ahlmèn EM. Development and evaluation of a patient education program for persons with systemic sclerosis (scleroderma). Arthritis Care Res 2000; 13: 141-148. 